JOANNA KOZIEŁ

\title{
SPECYFIKA NAUCZANIA LEKSYKI JEZZYKA OBCEGO W PRZYPADKU UCZNIÓW Z MYŚLENIEM O CHARAKTERZE KLIPOWYM
}

Nowe warunki socjo-technologiczne wpłynęły na ukształtowanie pokolenia, dla którego tradycyjne, tekstocentryczne metody nauczania stają się coraz mniej efektywne. Psychologia Internetu zwraca uwagę na zmiany zachodzące w strukturze mózgu osób od wczesnych lat życia korzystających z urządzeń elektronicznych. Choć wciąż trwają badania tego problemu, to jednak wątpliwości nie pozostawiają transformacje we wzorcach myślenia i zachowania pokolenia online (Jabłońska 16). Cyberprzestrzeń jest częścią tożsamości młodych ludzi, dlatego oczywiste są postulaty dotyczące konieczności stosowania technologii informacyjno-komunikacyjnych (dalej: TIK) w procesie dydaktycznym. Bez wątpienia przełomowym w tej kwestii był rok 2020, kiedy to po raz pierwszy e-learning przestał pełnić funkcję drugoplanową, dodatkową, tymczasowo zamieniając się w podstawowy sposób nauczania. Choć trudno przewidzieć, jakie długoterminowe konsekwencje pociągną za sobą doświadczenia czasu kwarantanny, to bez wątpienia edukacja zdalna potwierdziła trwały związek technologii wirtualnych z każdym aspektem życia „cyfrowych tubylców”, a także uwypukliła problem myślenia o charakterze klipowym. Niniejszy artykuł nie stanowi krytyki zachodzących przemian, bo wraz z rozwojem cyfryzacji zmiany niewątpliwie są nieuchronne i nieodwracalne. Celem postawionym przez autorkę jest natomiast próba odnalezienia narzędzi, wykorzystujących specyfikę takiego typu myślenia (zapamiętywania) do skuteczniejszego nauczania oraz rozwijania krytycznego

Dr Joanna KozıeŁ - Katolicki Uniwersytet Lubelski Jana Pawła II, Wydział Nauk Humanistycznych, Instytut Językoznawstwa, Katedra Translatoryki i Języków Słowiańskich; e-mail: joanna.koziel@kul.pl; ORCID: 0000-0002-0054-7685. 
podejścia do informacji. W pierwszej części artykułu uwagę skoncentrowano na charakterystyce profilu ucznia z myśleniem klipowym w kontekście jego potrzeb dydaktycznych. Następnie podjęto próbę wydzielenia metod oferowanych przez językoznawstwo kognitywne, które mogą okazać się pomocne w nauczaniu w takiej grupie leksyki języka obcego na przykładzie języka rosyjskiego.

Rozważania należy rozpocząć od samego pojęcia „myślenie klipowe”. Termin ten nie jest dostatecznie utrwalony w polskim dyskursie naukowym, natomiast często, począwszy od prac Fiodora Girienoka z początku XXI wieku, używają go w swoich pracach badacze rosyjscy. Za twórcę koncepcji uznaje się futurologa Alvina Tofflera, który w monografii Trzecia fala (oryg. Third Wave) $)^{2}$ wprowadził określenie „kultura klipowa” („blip culture”). Toffler opisywał przemiany zachodzące m.in. w środkach masowego przekazu i wpływ, jaki mogą wywierać na funkcjonowanie mózgu. Zgodnie z jego przewidywaniami zauważalne jest radykalne zwiększenie bodźców napływających do ludzi:

A w wymiarze indywidualnym każdego człowieka osaczają i zewsząd atakują wyobrażenia fragmentaryczne, sprzeczne lub niepowiązane ze sobą, które podważają jego dawne idee i trafiają do świadomości w postaci jakichś niepełnych lub wyrwanych z kontekstu elektronicznych impulsów. (Toffler 197)

Ów strumień napływających informacji przypomina swoją strukturą klip - utwór składający się z luźno z sobą powiązanych obrazów, powierzchownie pokazujących określane zjawiska, fakty, najczęściej akcentując ich najbardziej jaskrawe przejawy. Myślenie klipowe jest natomiast próbą dostosowania się mózgu do tych warunków, mającą chronić od przeciążenia nadmiarem informacyjnym. Tego procesu nie można jednoznacznie krytykować, ponieważ stanowi przykład zmiany jednych kognitywnych nawyków na inne (Semenovskikh 5). Wydzielanie danego rodzaju myślenia jako nowej tendencji, charakterystycznej dla czasów najnowszych, może budzić zastrzeżenia, ponieważ osoby z podobnym rodzajem pamięci spotykano już wcześniej

\footnotetext{
${ }^{1} \mathrm{~W}$ polskim przekładzie monografii Third Wave Alvina Tofflera, twórcy tego pojęcia, angielski termin „blip culture” przetłumaczono jako „kultura impulsów”. Ten typ kultury w konsekwencji prowadzi do „myślenia klipowego” („myślenia impulsami”). W dyskursie naukowym spotyka się również terminy synonimiczne: „myślenie mozaikowe” lub „myślenie o charakterze klipowym”. W literaturze rosyjskiej przeważa tłumaczenie „клиповая культура” bądź rzadziej „блип культура”. W niniejszym artykule stosuje się zasadniczo termin „myślenie klipowe”, który zdaniem autorki najtrafniej oddaje istotę zjawiska.

${ }^{2}$ The Third Wave została opublikowana w 1980 r. przez Bantam Books, pierwsze polskie pełne wydanie przez PIW w 1997 r., wydanie drugie przez Wydawnictwo Kurpisz w 2006 r.
} 
(Makarovska 134). W ostatnich jednak latach, wraz z rozpowszechnieniem urządzeń multimedialnych, nastąpiła intensyfikacja zjawiska.

\section{CHARAKTERYSTYKA OSÓB Z MYŚLENIEM KLIPOWYM}

Duża liczba bodźców napływających jednocześnie z wielu źródeł przekracza zdolności adaptacyjne człowieka, dlatego nie jest on w stanie przetwarzać ich - analizować czy poddawać głębszej refleksji. Bogactwo informacyjne powoduje tym samym utratę koncentracji na rzecz powierzchownego poznania i niemożności ugruntowania wiedzy. W konsekwencji wymusza to nieustanne aktywizowanie pamięci krótkotrwałej z jednoczesnym zmniejszeniem wykorzystania obszaru pamięci długotrwałej. Zapamiętana informacja zostaje tym samym często pozbawiona kontekstu, co skutkuje trudnościami w późniejszym łączeniu faktów oraz wskazywaniu ich przyczyn czy skutków. W warunkach szkolnych tej sytuacji sprzyja koncepcja programów nauczania $\mathrm{z}$ podziałem na poszczególne przedmioty lekcyjne. Ścisłe rozgraniczanie treści zajęć, duże obciążenie materiałem, utrudniające prowadzenie systematycznych powtórek, potęgują problemy z kontekstualizacją oraz kodowaniem danych w pamięci długotrwałej.

Jak już wspomniano, specyficzną cechą dla osób z myśleniem klipowym jest również obniżona koncentracja. Praca $z$ dłuższymi jednorodnymi tekstami szybko wywołuje znudzenie oraz zniechęcenie. Svetlana Simakova twierdzi, że „epokę Zuckerberga”, która zastąpiła, przynajmniej po części, „epokę Gutenberga”, cechuje szybkie określanie sensu komunikatu pisemnego na podstawie przeczytanego akapitu czy ilustracji, a także preferowanie piktogramów zamiast tekstu ciągłego (Simakova 111). Młodzi ludzie niejako „skanują” oczami tekst w poszukiwaniu interesujących danych. Jednym z czynników warunkujących dane zjawisko jest niestanne korzystanie z urządzeń o małych ekranach, np. smartfonów, tabletów. Brak szerokiego pola widzenia utrudnia pozyskiwanie szczegółowych informacji i głębszą analizę tekstu (Kraynov 263). Obserwując te przekształcenia, można zauważyć zmianę stylu czytania - odejście od linearności w stronę schematu sieciowego. Odbiorca odczuwa potrzebę reorganizowania tekstów analogicznie do budowy stron internetowych - zamieszczania hipertekstów, pozwalających na możliwość przełączania się między danymi oraz swoiste żonglowanie nimi (Szymańska 100-101). Powyższa tendencja przekłada się też na tworzenie dłuższych, spójnych wypowiedzi zarówno ustnych, jak i pisemnych, które coraz 
częściej zaczynają sprawiać trudności. O wiele bardziej efektywne od takich komunikatów są wizualne sposoby przekazywania informacji - zwiększają stopień przyswajalności treści nawet o 55\% (Sładkiewicz i Noińska 169). Na kwestię dominacji obrazu zwracano uwagę już w ubiegłym wieku. Poświadcza to chociażby koncepcja homo videns, którą w 1998 r. sformułował Giovanni Sartori. Jednoznacznej krytyce badacz poddawał wpływ mediów audiowizualnych na człowieka, gdyż te, jego zdaniem, obniżają zdolność do myślenia abstrakcyjnego, oddając pierwszeństwo myśleniu obrazowemu. Jak podsumowuje, ,telewizja wytwarza obrazy i niszczy idee” (Sartori 27). Taką tendencję obserwuje się także u osób z myśleniem klipowym potrzeba otrzymywania bodźców wizualnych i audiowizualnych powoduje w konsekwencji skupianie się na warstwie emocjonalnej kosztem logiczno-racjonalnej (Makarovska 136). Ponadto wizualność zaczyna coraz bardziej wkraczać do tekstów pisanych, np. za pomocą ideogramów - emotikonów, bez których niełatwo już przekazać warstwę emocjonalną komunikatu. Warto podkreślić, że powyższe cechy - preferowanie obrazu oraz nowy styl czytania - zauważyli autorzy podręczników. Najnowsze wydania są bogate w materiał ilustracyjny, mają wielobarwną szatę graficzną i znacznie ograniczają linearną strukturę tekstu.

Należy nadmienić, że myślenie klipowe nie ma jednoznacznie negatywnego wymiaru, ponieważ niesie $\mathrm{z}$ sobą rozwój pozytywnych kompetencji. Gwałtowny napływ informacji dochodzących z wielu kanałów upowszechnił umiejętność błyskawicznego przechodzenia od jednych danych do innych, a także korzystnie wpłynął na szybkość reakcji. Nierzadko tak zwani cyfrowi tubylcy cechują się szerokimi zainteresowaniami z różnych dyscyplin. Dlatego też nie boją się wchodzić $\mathrm{w}$ dyskusje czy podejmować ryzyka popełnienia błędu. Zwiększenie liczby dochodzących do mózgu impulsów usprawniło także działanie pamięci krótkotrwałej oraz zapamiętywanie prostych danych, np. listy słów czy liczb (Semenovskikh 6). Oprócz tego zjawiskiem powszechnym stała się wielozadaniowość, choć nie można jej rozpatrywać wyłącznie jako zalety. Młodzi ludzie potrafią jednocześnie słuchać muzyki, prowadzić konwersacje na portalu społecznościowym i odrabiać pracę domową, co niejednokrotnie rzutuje jednak na jakość podejmowanych działań. Za wielozadaniowością często kryje się bowiem roztargnienie i deficyt uwagi. Stanowi ona zarazem swego rodzaju konieczność, bez której szybko pojawia się poczucie znudzenia. Taką tendencję można zaobserwować chociażby na zajęciach dydaktycznych, kiedy to coraz większą trudność sprawia utrzymanie koncentracji uwagi ucznia bez zastosowania TIK czy technik aktywizujących. 
Korzystanie z wielu źródeł ma również pozytywny wpływ na wzrost kreatywności młodych ludzi zarówno w zakresie stosowanych narzędzi, jak i sposobów rozwiązywania problemów. Cyberprzestrzeń daje możliwość łatwego dostępu do wiedzy oraz poczucie braku ograniczeń, co może, z jednej strony, skutkować płytkością wiedzy, a z drugiej wprost przeciwnie - szerokim rozpatrywaniem zagadnienia oraz tworzeniem swoistej mapy powiązań. Do tego jednak najczęściej potrzebne jest wsparcie dydaktyka. Jego rola powinna się skupiać na niwelowaniu negatywnych aspektów myślenia klipowego i jednocześnie rozwijaniu korzystnych stron tego zjawiska.

\section{PRACA DYDAKTYCZNA A MYŚLENIE KLIPOWE}

Nie sposób pominąć faktu, że w ostatnim czasie do pracy dydaktycznej na zajęciach z języków obcych wprowadzono wiele metod, które w dużej mierze odpowiadają potrzebom osób z myśleniem klipowym. Często natomiast nie są stosowane systematycznie, a ich aplikacja ogranicza się przede wszystkim do zajęć powtórzeniowych lub funkcji nagrody. Celem niniejszego artykułu jest próba scharakteryzowania sposobów pracy i typów zadań wraz z podaniem przykładów, które pozwolą uatrakcyjnić lekcje oraz pomóc w opanowaniu materiału omawianej grupie odbiorców. Ćwiczenia te są przeznaczone do wykorzystania przede wszystkim w pracy edukacyjnej z uczniami szkół ponadpodstawowych, można je jednak z powodzeniem wykorzystywać także na zajęciach praktycznej nauki języka obcego na uczelniach wyższych ${ }^{3}$.

Na potrzeby osób z myśleniem klipowym w dużej mierze odpowiada podejście kognitywne w edukacji. Ze względu na stosunkowo krótką formę, jaką stanowi artykuł naukowy, niemożliwa jest pełna jego charakterystyka, dlatego wyekscerpowano wyłącznie elementy najistotniejsze z perspektywy omawianego zagadnienia. Podejście kognitywne podkreśla przede wszystkim konieczność nauczania holistycznego ${ }^{4}$. Po pierwsze, pozwala to na lepsze utrwalanie materiału, ponieważ jest on wielokroć powtarzany i rozpatrywany z różnych perspektyw, co jednocześnie w znacznym stopniu poprawia jego zrozumienie. Dzięki temu uczeń może kształtować umiejętność swobodnego

\footnotetext{
${ }^{3}$ Potrzebę wprowadzenia metod skierowanych do osób z myśleniem klipowym potwierdzają badania A. Klimkiewicz (65-76).

${ }^{4}$ Nauczanie holistyczne zakłada edukację transdyscyplinarną, całościową, skoncentrowaną na procesie uczenia się i uczniu, nie zaś nauczaniu oraz nauczanej dyscyplinie. Ważne jest w nim indywidualne doświadczenie, a także pogłębianie świadomości ucznia (Miller 4).
} 
operowania informacjami - łączenia ich, doszukiwania się przyczyn i skutków, a w konsekwencji tworzenia logicznej, koherentnej całości. Po drugie, poprzez całościowy ogląd zagadnienia taka technika ułatwia formowanie krytycznego myślenia, które odgrywa szczególnie ważną rolę w przypadku korzystania ze źródeł internetowych. Wprowadzenie pełnej edukacji holistycznej wiąże się z głębszymi reformami systemu oświaty, jednak w panujących obecnie warunkach możliwe jest stosowanie w pracy dydaktycznej nauczania kontekstowego ${ }^{5}$. Nie stanowi ono jakiegoś novum w glottodydaktyce, ponieważ już od wielu lat podkreśla się konieczność budowania kompetencji interkulturowej. Wprowadzanie materiału kulturoznawczego pozwala nie tylko na poszerzenie zasobu leksykalnego, ale również lepsze zrozumienie kontekstu językowego oraz ułatwia komunikację z nosicielami języka. Dotychczas powstało już wiele publikacji podkreślających wagę tego zagadnienia ${ }^{6}$, co również przekłada się na treść podręczników, w których można znaleźć rozdziały poświęcone m.in. atrakcjom turystycznym (np. rozdziały „Московский марафон - маршрут” w podręczniku Bom u мы noновому 1 M. Kmieciak-Wójcik i S. Wujec, „Интересные факты о Москве” w podręczniku Беседa 1 A. Pado), wybitnym postaciom czy ważnym świętom (np. „День Победы” w podręczniku Как каз 2 O. Tatarchyk). W przypadku uczniów z myśleniem klipowym nauczanie kontekstowe powinno zostać znacznie pogłębione i nawiązywać tak często, jak tylko jest to możliwe, do treści programowych innych przedmiotów, np. historii, historii sztuki, geografii. Nie musi się to odbywać w ramach wydzielonych zajęć, ale należy je przede wszystkim wplatać do codziennej pracy dydaktycznej. Niektóre kręgi tematyczne, jak np. kultura czy świat przyrody, są skorelowane $\mathrm{z}$ innymi przedmiotami, ale również pozostałe kręgi można rozpatrywać z tej perspektywy. Poniżej zaprezentowano przykładowe ćwiczenia, pozwalające wykorzystać nauczanie kontekstowe podczas lekcji języka rosyjskiego (tabela 1).

\footnotetext{
${ }^{5}$ Nauczania kontekstowego nie można traktować jako ekwiwalentu nauczania holistycznego, obydwa jednak nurty podkreślają konieczność zaniechania ścisłego rozgraniczania przedmiotów, a szukania między nimi powiązań, rozumienia relacji między nimi oraz rozpatrywania zagadnień z szerszej perspektywy.

${ }^{6}$ Por. np. Komorowska; Mackiewicz; Żydek-Bednarczuk.
} 
Tabela 1.

\begin{tabular}{|c|c|}
\hline $\begin{array}{l}\text { Krąg tematyczny } \\
\text { oraz zakres leksykalny }\end{array}$ & Przykłady ćwiczeń \\
\hline $\begin{array}{l}\text { Życie rodzinne i towarzyskie: } \\
\text { członkowie rodziny, znajomi } \\
\text { i przyjaciele }\end{array}$ & $\begin{array}{l}\text { - Przedstawianie członków rodziny i określanie ich pokrewieństwa } \\
\text { na przykładzie ostatniej carskiej rodziny Romanowów. Uczniowie } \\
\text { otrzymują wydrukowane i podpisane portrety lub wyszukują je samo- } \\
\text { dzielnie w Internecie, a następnie tworzą drzewo genealogiczne. }\end{array}$ \\
\hline $\begin{array}{l}\text { Człowiek: } \\
\text { a) wygląd zewnętrzny } \\
\text { b) cechy charakteru }\end{array}$ & $\begin{array}{l}\text { - Opisywanie wyglądu zewnętrznego oraz cech charakteru postaci } \\
\text { z wykorzystaniem malarstwa rosyjskiego, np. Dziewczynka zbrzoskwi- } \\
\text { niami W.A. Sierowa, Alonuszka W.M. Wasniecowa, Portret L.N. Tołstoja } \\
\text { I.N. Kramskiego, Carewna Łabędź M.A. Wrubla. } \\
\text { - Opisywanie wyglądu zewnętrznego oraz cech charakteru na przykładzie } \\
\text { bohaterów literatury rosyjskiej (uczniowie uprzednio powinni omówić } \\
\text { dane lektury na lekcjach językach polskiego), np. Mistrz i Małgorzata } \\
\text { M.A. Bułhakowa. }\end{array}$ \\
\hline Szkoła: życie szkoły & $\begin{array}{l}\text { - Edukacja w Instytucie Szlachetnie Urodzonych Panien w Petersburgu: } \\
\text { plan zajęć, życie uczennic. }\end{array}$ \\
\hline Podróżowanie i turystyka & $\begin{array}{l}\text { - Praca z mapą Rosji: odszukiwanie i określanie położenia największych } \\
\text { miast, obszarów atrakcyjnych turystycznie. } \\
\text { - Pokaz filmu Choinki w reż. Timura Bekmambetova. W trakcie seansu } \\
\text { uczniowie zaznaczają na mapie konturowej Rosji miasta, w których toczy } \\
\text { się akcja filmu. }\end{array}$ \\
\hline
\end{tabular}

Także materiał gramatyczny może stać się punktem wyjścia do integracji międzyprzedmiotowej. W tym wypadku najprostszym sposobem jest tworzenie zadań (np. ćwiczeń typu wpisywanie odpowiedniej formy wyrazów podanych $\mathrm{w}$ nawiasie) $\mathrm{z}$ wykorzystaniem autentycznych postaci, dat czy istotnych wydarzeń w historii Rosji (tabela 2.). Gdy uczniowie rozwiązują poszczególne przykłady, nauczyciel może sprawdzać, czy posiadają oni wiedzę na temat określonych osób lub zdarzeń, jeśli nie - uzupełnić informacje.

\section{Tabela 2.}

\section{Proszę wstawić czasowniki z nawiasów w odpowiedniej formie czasu przeszłego.}

1. Анна Павлова .......... русской артисткой балета. (быть)

2. Владимир Святославич .......... Русь в 988 году. (крестить)

3. Аральское море уже почти совсем .......... (исчезнуть)

4. Иван Петрович Павлов .......... Нобелевскую премию. (получить)

5. Дмитрий Иванович Менделеев .......... периодическую таблицу. (создать)

6. Родион Раскольников ......... в Петербурге. (жить)

\footnotetext{
${ }^{7}$ Kręgi tematyczne wydzielone na podstawie Coste, North, Sheils i Trim oraz Broniarz.
} 
Olga Makarovska wskazuje, że kluczowe jest aktywizowanie pamięci długotrwałej poprzez systematyczne nawiązywanie do omawianego uprzednio materiału i wskazywanie łączności z zagadnieniem obecnie prezentowanym, np. za pomocą pytań, np. „Помните, мы с вами говорили о....”, lub podkreślania dalszej perspektywy, np. „Обратите внимание на ... - это нам пригодится, когда мы будем говорить о...” (Makarovska 141). Prowadzenie zajęć z wykorzystaniem nauczania kontekstowego można uważać za atrakcyjne dla osób z myśleniem klipowym, ponieważ swoją strukturą przypomina sieciową strukturę Internetu. Działania nauczyciela przywodzą na myśl tworzenie hiperlinków umożliwiających płynne przechodzenie od jednych informacji do innych.

Podejście kognitywne postuluje również to, co jest ważne dla młodych ludzi - wskazuje na odrębność człowieka jako nadawcy i zarazem odbiorcy komunikatu. Tego właśnie młodzież oczekuje od swojego otoczenia - kieruje nią pragnienie bycia zauważonym, dlatego w wirtualnej przestrzeni prezentuje swoje życie, np. zamieszczając fotografie, i oczekuje na uwzględnienie własnego punktu widzenia, publikując komentarze. Jak wskazują językoznawcy, język umożliwia indywidualistyczne wyrażanie siebie, jest narzędziem do poznawania oraz doświadczania rzeczywistości w sposób właściwy dla konkretnej osoby (Szymańska 145-146). Znajomość języka obcego rozszerza tę możliwość. Dlatego pozytywne efekty przynosi uświadomienie uczniom ich potencjału twórczego, a także określenie celu nauki. W procesie nauczania ważne jest bowiem wskazanie na pragmatyczną stronę poznawanego materiału - młodzi ludzie muszą wiedzieć, po co uczą się danego języka, oraz mieć szansę na wykorzystanie go w praktyce. Choć perspektywa wyjazdu do Rosji często pozostaje sprawą dość abstrakcyjną dla uczniów, a kontakt z osobami rosyjskojęzycznymi bywa utrudniony, komunikowanie się po rosyjsku umożliwia przestrzeń wirtualna. Korzystanie np. z rosyjskich forów czy tworzenie komentarzy do postów rosyjskich użytkowników portali społecznościowych to ciekawy sposób na doskonalenie kompetencji komunikacyjnej. Poza tym gwarantuje autentyzm językowy oraz odpowiada na potrzebę działania. Ponieważ leksyka wirtualnego świata $\mathrm{w}$ znacznej mierze jest oparta na słownictwie potocznym, pozwala na zanurzenie się $\mathrm{w}$ naturalnym środowisku języka $\mathrm{i}$ pomaga w kształtowaniu intuicji językowej. W tabeli 3 zaprezentowano przykładowe ćwiczenia pozwalające wykorzystać cyberprzestrzeń na lekcji lub w ramach pracy pozaszkolnej. Zawarte tu zadania uwzględniają nauczanie kontekstowe. 
Tabela 3.

\begin{tabular}{|l|l|}
\hline $\begin{array}{l}\text { Krąg tematyczny } \\
\text { oraz zakres leksykalny }\end{array}$ & \multicolumn{1}{|c|}{ Przykłady ćwiczeń } \\
\hline Podróżowanie i turystyka & $\begin{array}{l}\text { - Uczniowie wpisują w wyszukiwarce Instagrama \#nyтewe- } \\
\text { cтвияnopoccun, wybierają kilka zdjęć i odpowiadają na przy- } \\
\text { gotowane uprzednio pytania np. o cel podróży, sposób spędzania } \\
\text { czasu, pogodę, towarzyszy podróży. }\end{array}$ \\
\hline Mój dzień & $\begin{array}{l}\text { - Uczniowie pracują w grupach. Otrzymują listę wideoblogów ze } \\
\text { strony YouTube, prezentujących czynności dnia codziennego } \\
\text { autorów. Samodzielnie dokonują wyboru nagrania, a po zapoz- } \\
\text { naniu się z materiałem uzupełniają kartę z pytaniami dostoso- } \\
\text { wanymi do znajomości leksyki np. co bohater jadł na śniadanie, } \\
\text { gdzie pracuje lub uczy się, jakie czynności wykonuje. Następnie } \\
\text { prezentują życie tej osoby pozostałym grupom. }\end{array}$ \\
\hline $\begin{array}{l}\text { Żywienie: posiłki i ich przy- } \\
\text { gotowanie }\end{array}$ & $\begin{array}{l}\text { Uczniowie nagrywają krótki film kulinarny w języku rosyjskim, na } \\
\text { którym prezentują, jak krok po kroku przygotować wybrane danie. }\end{array}$ \\
\hline
\end{tabular}

Podejście kognitywne podkreśla rolę uczącego się w pozyskiwaniu wiedzy. Młodzi odbiorcy odczuwają potrzebę samodzielnego poszukiwania informacji, a metody implicytnego dochodzenia do wiedzy znacznie poprawiają umiejętność zapamiętywania materiału. Pedagog powinien pomagać uczniowi w kształtowaniu kompetencji efektywnego wykorzystania narzędzi, w tym wyszukiwarek internetowych, a także w formowaniu rzetelności informacyjnej poprzez dobór wiarygodnych źródeł. Popularnym sposobem kształtowania tej umiejętności jest metoda projektowa, w sposób szczególny ceniona $w$ dydaktyce języka angielskiego. Jako zaletę podkreśla się przede wszystkim wyzwalanie energii twórczej, wspieranie autonomii ucznia oraz aktywizowanie go.

Samodzielną pracę uczniów można wykorzystywać również do przygotowywania banków leksyki. O ile tradycyjne, zapisywane w zeszycie słowniczki zazwyczaj nie są dla osób z myśleniem klipowym ani ciekawe, ani skuteczne $\mathrm{w}$ nauce, o tyle Internet wychodzi naprzeciw ich oczekiwaniom. Jednym $\mathrm{z}$ atrakcyjnych narzędzi edukacyjnych jest strona Quizlet, dostępna również w formie aplikacji mobilnej. Poprzez przejrzystą szatę graficzną, różnorodność ćwiczeń i bodźców Quizlet w pełni odpowiada potrzebom osób z myśleniem klipowym. Uczeń sam tworzy banki słów lub korzysta $\mathrm{z}$ istniejących zestawów. Strona oferuje kilka modułów do nauki (m.in. fiszki, testy, grywalizację), które obejmują zróżnicowane czynności, np. odsłuchiwanie kwestii 
wypowiadanych przez lektora, pisanie, testy, rozumienie ze słuchu czy dopasowywanie. Ponadto naukę leksyki wspierają dobrane do poszczególnych słów ilustracje. Uczeń, wykonując ćwiczenia, dostaje natychmiastową informację zwrotną z wynikami, widzi postęp osiągany w opanowaniu materiału, a jego praca jest „nagradzana” pochlebnymi komunikatami lub motywacją do powtórek. Jak wskazują badania prowadzone w różnych grupach wiekowych uczniów, korzystanie ze strony Quizlet ocenia się jednoznacznie pozytywnie. Użytkownicy podkreślają efektywność, a przede wszystkim wygodę i radość, jaką daje taka metoda nauki leksyki (Okkan i Aydin).

Problem myślenia klipowego będzie się z pewnością nasilał się, bo jest on nieuniknionym elementem postępującej immersji w świat wirtualny, którą obserwuje się u młodych ludzi. Nauczyciele muszą wypracować metody skutecznie niwelujące negatywne strony tej tendencji. W poszukiwaniach efektywnych środków dydaktycznych pomocne okazują się postulaty podejścia kognitywnego. Wśród uczniów z myśleniem klipowym szczególną uwagę należałoby poświęcić nauczaniu holistycznemu, wskazywaniu na przyczyny i skutki wydarzeń czy kształtowaniu umiejętności tworzenia koherentnego obrazu. Stosowanie technik aktywizujących oraz wykorzystywanie TIK zdecydowanie pozytywnie wpływa na proces dydaktyczny.

\section{BIBLIOGRAFIA}

Broniarz, Renata. Programu nauczania języka rosyjskiego jako drugiego języka obcego w 4-letnim liceum ogólnokształcacym i 5-letnim technikum (zgodny z wariantem podstawy programowej III.2.0. i III.2). WSiP, 2019.

Coste, Daniel, Brian North, Joseph Sheils i John Trim. Europejski system opisu ksztatcenia językowego: uczenie się, nauczanie, ocenianie. Tłum. Waldemar Martyniuk. Wydawnictwo Centralnego Ośrodka Doskonalenia Nauczycieli, 2003.

Jabłońska, Marta R. Człowiek w cyberprzestrzeni. Wprowadzenie do psychologii Internetu. Wydawnictwo Uniwersytetu Łódzkiego, 2018.

Klimkiewicz, Aleksandra. „Nowa rzeczywistość dydaktyczna w nauczaniu języka rosyjskiego: oczekiwania studentów vs proces nauczania”. Problemy współczesnej glottodydaktyki i nauczania przektadu, red. Joanna Mampe, Jolanta Hinc i Adam Jarosz, Wydawnictwo Uniwersytetu Gdańskiego, 2017, ss. 65-76.

Komorowska, Hanna. Metodyka nauczania języków obcych. Fraszka Edukacyjna, 2003.

Kraynov, Andrey Leonidovich. „Klipovoye myshleniye v kontekste obrazovatel'nykh praktik: sotsial'no-filosofskiy analiz". Izvestiya saratovskogo universiteta. Novaya seriya. Seriya: Filosofiya. Psikhologiya. Pedagogika, nr 3 (19), 2019, ss. 262-266 [Крайнов, Андрей Леонидович. „Клиповое мышление в контексте образовательных практик: социально-философский анализ". Известия Саратовского университета. Новая серия. Серия Философия. Психология. Педагогика, № 3 (19), 2019, сс. 262-266]. 
Mackiewicz, Maciej. Dydaktyka języków obcych a kompetencja kulturowa i komunikacja interkulturowa. Wydawnictwo Wyższej Szkoły Bankowej, 2005.

Makarovska, Olga. „Klipovost' myshleniya i formirovaniye mezhkul'turnoy kompetentsii”. Studia Rossica Posnaniensia, t. 35, 2010, ss. 133-134 [Макаровска, Ольга. „Клиповость мышления и формирование межкультурной компетенции”. Studia Rossica Posnaniensia, t. 35, 2010, cc. 133-134].

Miller, John P., redaktor, Holistic Learning and Spirituality in Education: Breaking New Ground. State University of New York Press, 2005.

Okkan, Ahmet i Aydin, Selami. „The Effects of the Use of Quizlet on Vocabulary Learning Motivation”. Language and Technology, $\mathrm{nr} 2$ (1), 2020 ss. 16-25.

Sartori, Giovanni. Homo videns. Telewizja i postmyślenie. Tłum. Józef Uszyński. Wydawnictwo Uniwersytetu Warszawskiego, 2007.

Semenovskikh, Tat'yana Viktorovna. „Fenomen «klipovogo myshleniya» v obrazovatel'noy vuzovskoy srede”. Naukovedeniye, nr 5 (24), 2014 [Семеновских, Татьяна Викторовна. „Феномен «Клипового мышления» в образовательной вузовской среде”. Науковедение, № 5 (24), 2014], Науковедение, naukovedenie.ru/PDF/105PVN514.pdf. Dostęp 01.07.2020.

Simakova, Svetlana Ivanovna. „Klipovizatsiya myshleniya u molodezhikak sledstviye razvitiya vizual'nykh kommunikatsiy v SMI". Znak: problemnoye pole mediaobrazovaniya: nauchnyy zhurnal, nr 2 (24), 2017, ss. 107-118 [Симакова, Светлана Ивановна. „Клиповизация мышления у молодежикак следствие развития визуальных коммуникаций в СМИ". Знак: проблемное поле медиаобразования: научный журнал, № 2 (24), 2017, cc. 107-118].

Sładkiewicz, Żanna, i Marta Noińska. „O roli nauczania elementów niewerbalnych na lekcjach języka obcego (na przykładzie gestów polskich i rosyjskich)”. Problemy współczesnej glottodydaktyki i nauczania przekładu, red. Joanna Mampe, Jolanta Hinc i Adam Jarosz. Wydawnictwo Uniwersytetu Gdańskiego, 2017, ss. 169-186.

Szymańska, Marta. Między nauka o języku a rozwijaniem języka. Koncepcje kształcenia językowego na przełomie XX i XXI wieku. Wydawnictwo Naukowe Uniwersytetu Pedagogicznego w Krakowie, 2016.

Toffler, Alvin. Trzecia fala. Tłum. Ewa Woydyłł i Michał Kłobukowski. Wydawnictwo Kurpisz S.A., 2006.

Żydek-Bednarczuk, Urszula. Spotkanie kultur. Komunikacja i edukacja międzykulturowa w glottodydaktyce. Wydawnictwo Uniwersytetu Śląskiego w Katowicach, 2015.

\section{SPECYFIKA NAUCZANIA LEKSYKI JĘZYKA OBCEGO W PRZYPADKU UCZNIÓW Z MYŚLENIEM O CHARAKTERZE KLIPOWYM}

Streszczenie

Artykuł stanowi próbę przybliżenia zjawiska myślenia klipowego. Termin ten, choć mało rozpowszechniony w polskim dyskursie naukowym, trafnie wskazuje na istotne zmiany, które dokonały się w umysłach pokolenia „cyfrowych tubylców”. W dobie postępującej cyfryzacji coraz częstsze stały się bowiem problemy związane $\mathrm{z}$ deficytem uwagi. $\mathrm{Z}$ jednej strony obserwuje się tendencję do powierzchownego przyjmowania informacji i generalizacji, co w konsekwencji utrudnia całościowe rozumienie zjawiska, pozbawia umiejętności krytycznego myślenia. Z drugiej zaś strony myślenie klipowe może nieść z sobą pozytywne aspekty. W artykule dokonano 
próby odnalezienia metod dydaktycznych, rozwijających korzystne strony tego zjawiska, które jednocześnie zwiększają efektywność i atrakcyjność lekcji języka rosyjskiego jako obcego. Jako narzędzie metodologiczne wybrano podejście kognitywne. Przeprowadzona analiza wskazała, że szczególną uwagę należy zwrócić na nauczanie holistyczne oraz ćwiczenie umiejętności wskazywania przyczyn oraz skutków wydarzeń. Następnie autorka przedstawiła typy zadań, które mogą sprzyjać wprowadzaniu danych założeń do glottodydaktyki.

Słowa kluczowe: myślenie klipowe; społeczeństwo informacyjne; podejście kognitywne, glottodydaktyka.

\section{THE SPECIFICITY OF TEACHING FOREIGN LANGUAGE VOCABULARY IN THE CASE OF STUDENTS WITH 'CLIP THINKING'}

\section{S u m m a r y}

The aim of this article is to analyse the specificity of clip thinking as a phenomenon of our information society. The term "clip thinking" shows the changes that have taken place in the minds of "digital natives". On the one hand, students who clip think have a tendency to generalise information and develop "hypertext minds". On the other hand, clip thinking can have some positive aspects. This article is an attempt to find didactic methods which can develop the advantages of this phenomenon, and, at the same time, increase the effectiveness of lessons teaching Russian as a foreign language. The author demonstrates how to use the cognitive approach as a means of handling this problem in the educational process. The analysis indicates that special attention should be paid to holistic teaching and developing critical thinking and problem-solving skills. Finally, the author presents different types of exercises which are useful in teaching such digital natives.

Keywords: mosaic thinking; clip thinking; information society; cognitive style; glottodidactics. 